\title{
Effects of Heat Treatment on Microstructural Evolution in Additively-manu- factured Parts of Various Heights from Maraging Steel
}

Hana Jirková (0000-0003-4311-7797), Kateřina Opatová (0000-0002-4300-3442), Ludmila Kučerová (0000-00017154-7829), Ivana Zetková (0000-0003-2415-922X), Štěpán Jeníček (0000-0002-7492-7437), Karolína Burdová (0000-0003-1694-9475)

Regional Technological Institute, University of West Bohemia, Univerzitní 8, 30100 Pilsen, Czech Republic. Email: hstankov@rti.zcu.cz,opatovak@rti.zcu.cz, skal@rti.zcu.cz, zetkova@rti.zcu.cz, jeniceks@rti.zcu.cz,kburdova@rti.zcu.cz

Parts made by 3D printing must be subjected to heat treatment to achieve the required mechanical properties. With the development of additive manufacturing in various areas of industry, more and more complex components are being printed, which, in addition to their complicated shape, also have different printing heights. Sometimes, builds of different heights are created on a single build platform. When there is height difference, the step region is characterized by a steep increase in hardness. It may lead to problems related to mechanical properties. MS1 tool steel was chosen as the material for this experiment. Using DMLS (Direct Metal Laser Sintering), a build with considerably greater height was created on the build platform together with other parts. Metallographic examination of the printed part was carried out and its hardness profiles were measured prior to as well as after heat treatment. The drop in hardness in the build of different height was up to $40 \mathrm{HV} 10$. Solution annealing at $820^{\circ} \mathrm{C}$ removed the transition produced by building a single part, both in terms of microstructure and mechanical properties.

Keywords: Additive Manufacturing, Heat Treatment, Maraging Steel, MS1

\section{Introduction}

Additive manufacturing (AM) enables various types of parts for various purposes and from various materials to be produced in a flexible manner $[1,2]$. In this particular process, parts are built from powder layer-by-layer according to a digital model [1-4]. These layers are sintered together by means of a laser. With $\mathrm{AM}$, one can manufacture parts which are difficult to make by conventional technologies, such as forging, casting or machining [1]. AM is mainly used for making topology-optimized parts, delivering major material and cost savings [5]. Even intricate prototypes can be built in this manner, speeding up development efforts and manufacturing in various industrial sectors. One of the AM methods for making metal parts is direct metal laser sintering (DMLS) [5, 6].

The resulting quality of the additively-manufactured parts is governed by the manufacturing parameters, such as the laser setting, the powder layer thickness, the building direction as well as the layout of the supports, topology of the parts and their layout on the build platform. Post-processing is equally important [6-8]. In order to remove internal stress and obtain the desired mechanical properties, heat treatment is performed after the manufacture. A number of studies have been devoted to the effects of heat treatment on ultimate strength, notch toughness and fatigue [5, $9,10]$.
The building progress, and hence the movement of the laser beam across the build platform is controlled by many parameters, one of them being the occupancy of the build platform. The larger the surface area on a single plane of the build, the longer the building time and the interval between deposition of two layers. This also extends the time for removal of heat from a single layer into the interior of the build or the build platform. However, a difficulty arises when parts with different heights or one part with height relief are built on a single build platform. These protruding portions are then built at higher speeds, which entails heat removal within shorter time than in case of building parts across the entire build platform. In these locations, a transition is formed which may lead to defects. Therefore, this paper describes microstructural evolution prior to and after heat treatment in a build which had a notably greater height than the rest of the builds on the build platform.

\section{Experiments}

Martensitic tool steel MS1 was selected as the experimental material (Tab. 1). The parts were built from a powder supplied by the company EOS [11]. It is a high-strength steel which is used in aviation and space applications and in machinery industry [5, 9]. It is used for cold forming dies and for pressure die casting of heavy and light non-ferrous metals with low melting 
temperatures [12].

EOS M290 machine for additive manufacturing was employed with default pre-set parameters for the build interior (laser scanning speed $960 \mathrm{~mm} / \mathrm{s}$, laser power $285 \mathrm{~W}$, track spacing $0.11 \mathrm{~mm}$, laser track overlap $0.08 \mathrm{~mm}$ ) and a set of parameters for the part's contour (laser scanning speed $960 \mathrm{~mm} / \mathrm{s}$, laser power $285 \mathrm{~W}$ ). The purpose of the laser contour pass was to deliver the desired dimensions, shape and roughness of the parts. The thickness of the layer to be sintered was constant for both strategies: $0.04 \mathrm{~mm}$.

Tab. 1 Chemical composition of the experimental material $[w t . \%][11]$

\begin{tabular}{|c|c|c|c|c|c|c|}
\hline & $\mathrm{C}$ & $\mathrm{Co}$ & $\mathrm{Mo}$ & $\mathrm{Ni}$ & $\mathrm{Ti}$ & $\mathrm{Fe}$ \\
\hline \multirow{2}{*}{ MS1 } & $<0.03$ & $8.5-$ & $\begin{array}{c}4.5- \\
9.5\end{array}$ & $\begin{array}{c}17- \\
5.2\end{array}$ & $\begin{array}{c}0.6- \\
0.8\end{array}$ & $\begin{array}{c}\text { ba- } \\
\text { lance }\end{array}$ \\
\hline
\end{tabular}

The build in the form of a bushing of $140 \mathrm{~mm}$ height was manufactured on a single platform together with a gear housing of a single-purpose milling cutter whose height was a mere $72 \mathrm{~mm}$ (Fig. 1). After cutting away from the build platform, the bushing was cut up into slices of approximate thickness of $5 \mathrm{~mm}$. One of the slices was kept in as-built form and the rest were solution annealed. The annealing at $820^{\circ} \mathrm{C}$ was carried out in a furnace with a protective argon atmosphere. The annealing temperature was recommended by the material data sheet by EOS [11]. Various annealing parameters were tested. The sequences involved various cooling procedures either in air or in furnace. Furnace cooling was performed with the furnace flap open. Three different holding times were tested: 1, 3 or 4 hours. An additional procedure which was tested involved repeated triple annealing for 1 hour at $820^{\circ} \mathrm{C}$.

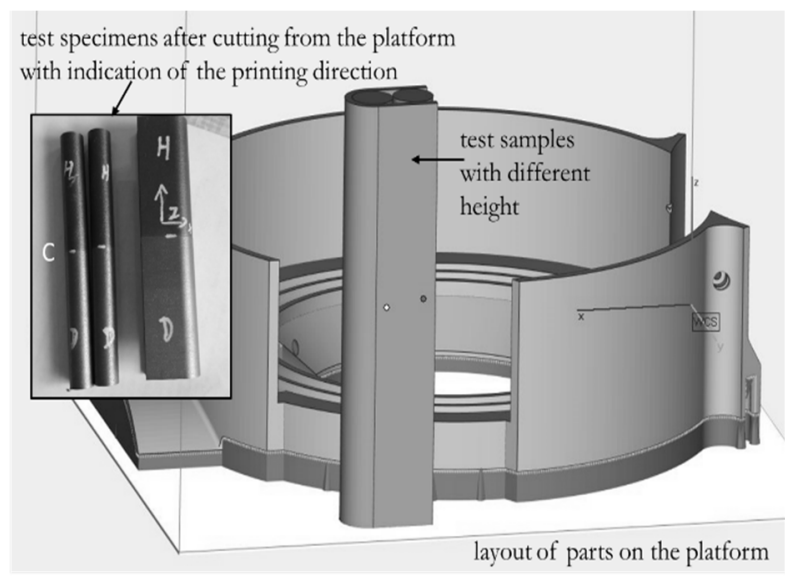

Fig. 1 Layout of builds on the build platform and finished builds with the transition region indicated $(D-$ build platform side, $\mathrm{H}$ - build end, C-transition region)

All slices were examined in three locations: near the platform (D), in the transition region (C) and at their end $(\mathrm{H})$. On all specimens, microscopic analysis was carried out on longitudinal sections using both optical microscopy (OM) and scanning electron microscopy with Zeiss EVO MA25. The amount of austenite was measured by means of XRD in the automatic powder diffractometer AXS Bruker D8 Discover with a position-sensitive area HI-STAR detector and a cobalt X-ray source $(\lambda \mathrm{K} \alpha=0.1790307 \mathrm{~nm})$. The instrument comprises polycapillary optics for focusing the primary X-ray beam into a circular spot with a diameter of $0.5 \mathrm{~mm}$. The measurement was conducted in the diffraction angle interval of 25$105^{\circ} 2$. Hardness profiles were determined using $1 \mathrm{~kg}$ Vickers scale, with impressions spaced at $0.5 \mathrm{~mm}$. Miniature tensile test was performed with specimens with a gauge section of $1.2 \times 2 \mathrm{~mm}$ and gauge length of $5 \mathrm{~mm}$. They were made by wire electrical discharge machining.

\section{Results and discussion}

\subsection{Microstructure analysis}

In the as-built slice (without heat treatment), the microstructure had the usual post-AM configuration (Fig. 2). With optical microscope, half-ellipse shapes formed by sintering individual layers and their overlapping were observed. Only a small amount of pores and microdefects caused by unsintered powder and gas caught in molten pools during solidification $[13,14]$. Scanning electron microscopy at higher magnifications revealed a cell structure within individual laser tracks. This type of structure forms by repeated local melting of the powder and its rapid solidification at high cooling rates. The macrostructure in the transition location $(\mathrm{C})$ between the uniform builds across the build platform and the test specimen was distinct after etching (Fig. 2). However, there were no visible differences within the interior. There was a difference in the amount of retained austenite related to the build height. Near the platform, there was 3\% retained austenite, whereas the other end of the specimen contained $7 \%$ austenite.

Changes were also found in the hardness profile (Fig. 3). At the bottom of the specimen (D) near the cut by which it was removed from the build platform, hardness was $370 \mathrm{HV} 1$. Across the specimen, hardness gradually decreased to $360 \mathrm{HV} 1$ at $72 \mathrm{~mm}$ distance, which is the height of the other parts on the build platform (point C) (Fig. 3). At this location, there was a drop in hardness to $320 \mathrm{HV} 1$, a constant value up to the end of the specimen (point $\mathrm{H}$ - farthest from the build platform). The variation in hardness along the length of the specimen was due to microstructural defects, such as pores and microdefects. In such locations, the indenter sunk into the material. 

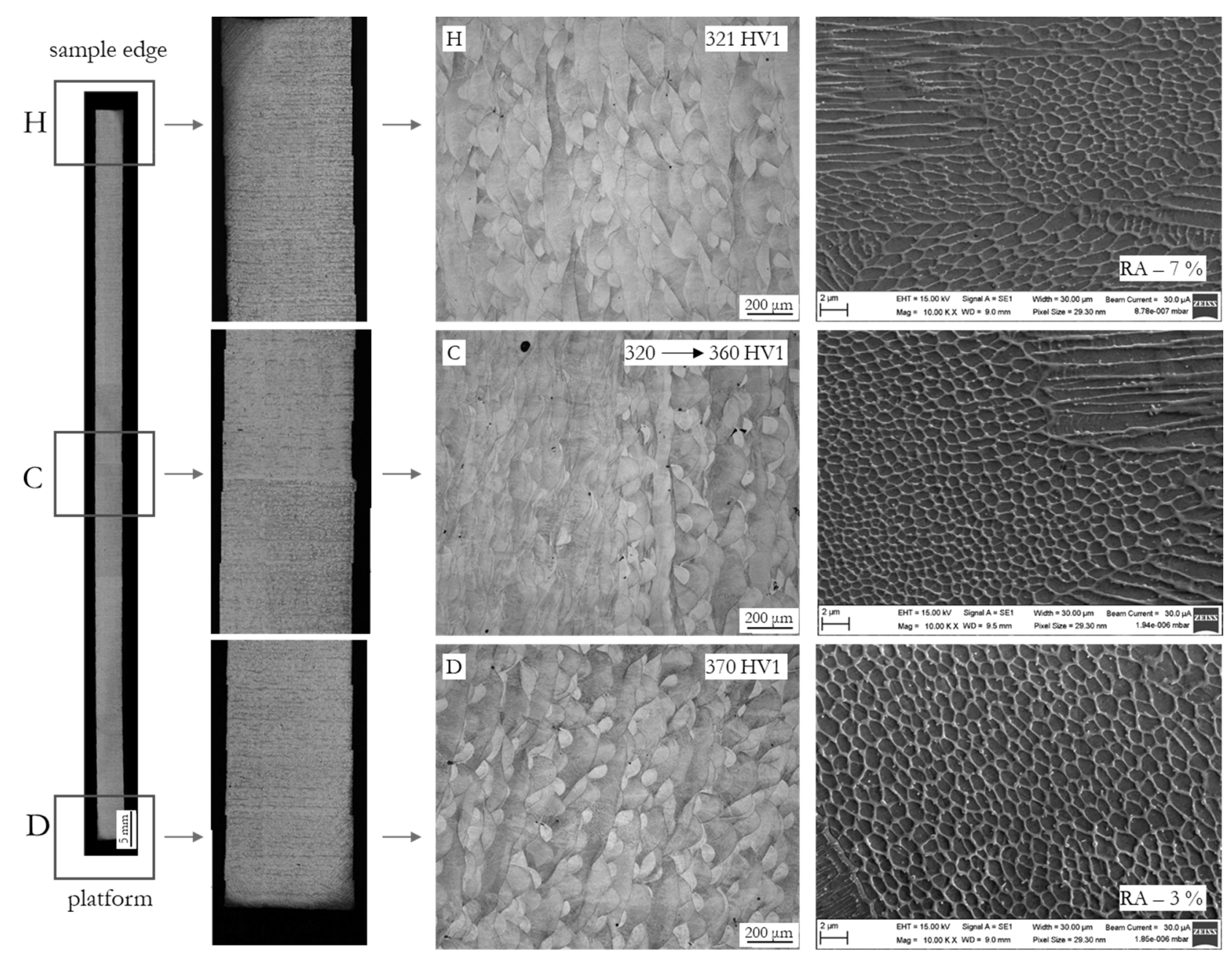

Fig. 2Optical and scanning electron microscopic analysis of the as-built slice without heat treatment

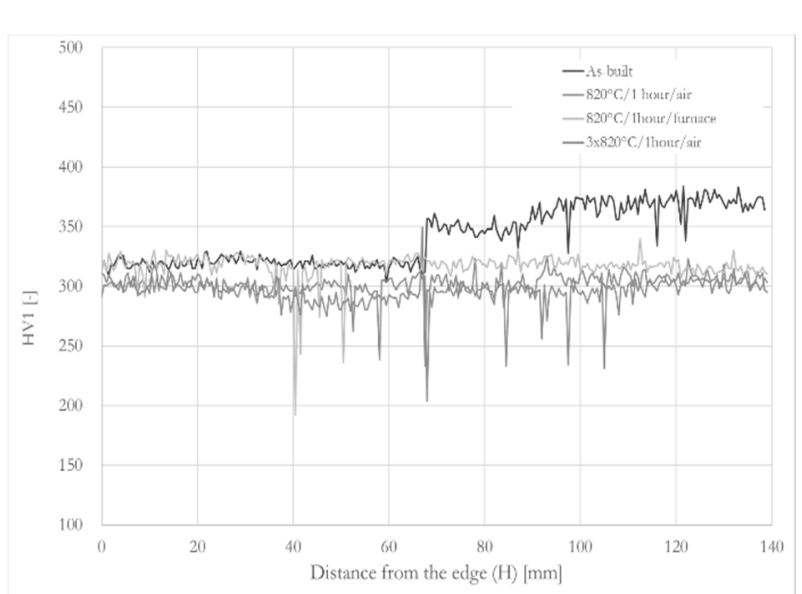

Fig. 3 Hardness profile along the length of the slice, as-built and solution annealed at various parameters

Solution annealing was carried out at $820^{\circ} \mathrm{C}$ for 1 hour, followed by cooling in air or furnace. Another sequence involved repeated triple annealing with holding times of 1 hour. The treated slices were examined in three locations again (Fig. 4). Solution annealing followed by air cooling and cooling in furnace produced a microstructure which was very similar to the as- built one. The features found in the as-built microstructure were still visible, including the halfellipses. However, within the tracks, decomposition of the as-built structure began to be visible. Signs of formation of a new internal structure were clearly visible after triple annealing at $820^{\circ} \mathrm{C}$. In location D near the platform, this decomposition was most distinct, having almost completely obscured the tracks (Fig. 4). The austenite content near the build platform was 1 to $2 \%$.

Hardness profiles were measured in this material as well (Fig. 3). The highest values, around 320 HV10 along the entire slice, were found in the furnacecooled specimen. This value was the same as in the top portion of the as-built specimen. In the air-cooled specimen and the repeatedly-annealed one, hardness was approximately $300 \mathrm{HV} 10$ along their entire len$\mathrm{gth}$. The decrease in hardness is due to dissolution of intermetallic precipitates and partial elimination of the cell structure produced by the AM process. Martensite is present in the form of martensite blocks or packets $[3,15]$. All annealing sequences removed the drop in hardness in the transition region, which was a desirable effect. 

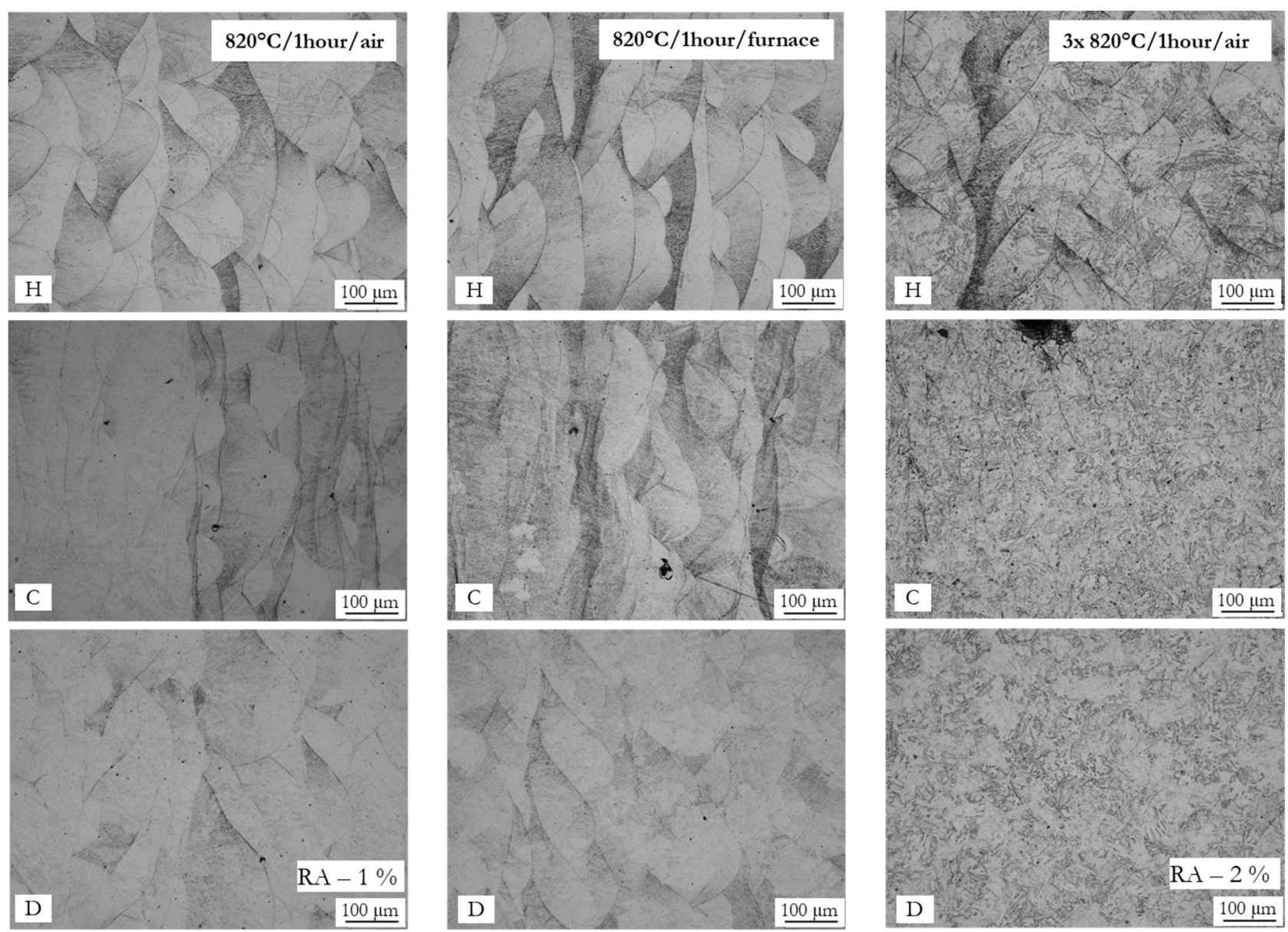

Fig. 4 Microstructure in the locations of interest in the slice upon solution annealing with a shorter holding time

After assessing the results of repeated annealing, annealing with 3 and 4 hour holding times followed by air cooling or furnace cooling was carried out. After these treatment sequences, location $\mathrm{D}$ near the build platform contained predominantly martensite. The laser tracks were not distinct any more. The microstructure was very similar to the one produced by triple short-time annealing. Closer to the specimen end, location $\mathrm{H}$ farthest from the platform, the as-built microstructure was partially preserved (Fig. 5). This difference in the microstructure configuration was not reflected in the hardness values: they were between 300 and 320 HV10 for all the conditions tested. The effect of cooling in air or in closed furnace was not manifested in the hardness values.

\subsection{Mechanical testing}

Based on metallographic examination, tensile testing was only performed for selected heat treatment sequences. This included the as-built and solution annealed condition $\left(820^{\circ} \mathrm{C}\right.$ with 1,3 and 4 hour holding times and furnace cooling (Fig. 6). In order to identify the effect of the transition between the build group and the individual build on mechanical properties, the transition region was tested as well. The mid-length of the specimen was at $72 \mathrm{~mm}$, where the drop in hardness occurred.
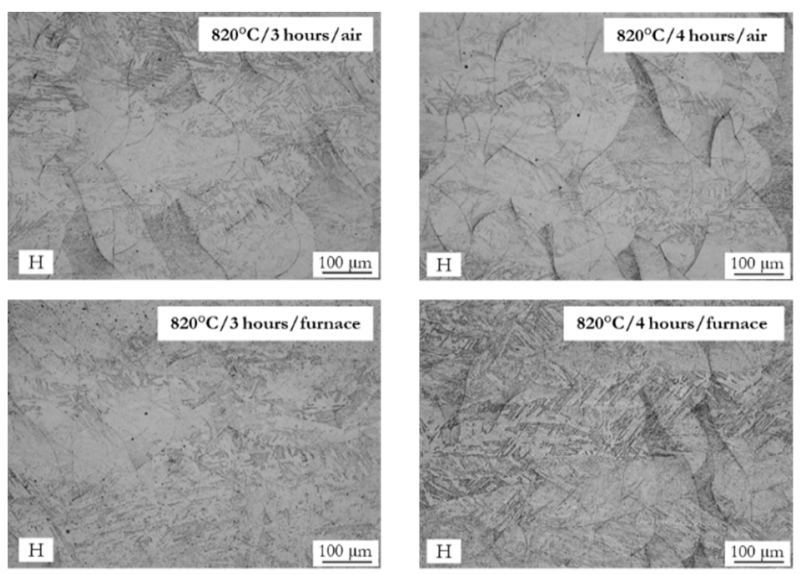

Fig. 5 Microstructure at the top part of the solution annealed slice (3 or 4 hours)

In the as-built condition, the highest ultimate strength was $1048 \mathrm{MPa}$, combined with an elongation of $22 \%$ near the platform. Towards the end of the specimen, ultimate strength decreased. In the transition region, ultimate strength was $963 \mathrm{MPa}$ and near the specimen end it was $927 \mathrm{MPa}$ but there was no substantial increase in elongation, which was $23 \%$. These 
results are in accordance with hardness values which decrease towards the specimen end.

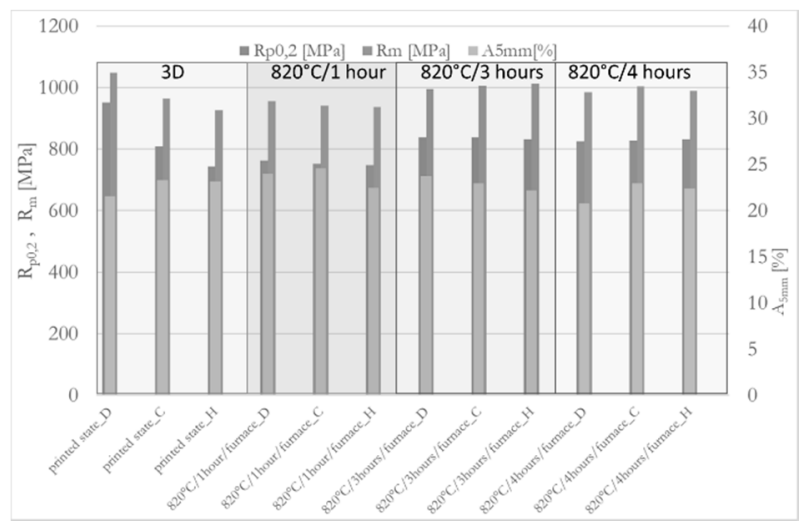

Fig. 6 Tension test data for as-built and treated specimens

After solution annealing, ultimate strength levels throughout the specimen equalized. Solution annealing for 1 hour produced an ultimate strength between 937 and $955 \mathrm{MPa}$ and an elongation between 22 and 24\% (Fig. 6). Upon 3 hour annealing, ultimate strength increased to 996 through $1012 \mathrm{MPa}$ and elongation was 22 to $24 \%$. Extending the holding time from 3 to 4 hours did not lead to substantial changes. Ultimate strength was between 984 and $1005 \mathrm{MPa}$ at an elongation of 21 to $23 \%$.

Although a macroscopic structural change was visible in the transition region after the AM process, as well as a drop in hardness, the mechanical properties did not deteriorate locally in this region. Although mechanical properties decreased with increasing height of the build, it was probably due to concurrent operation of multiple factors. As the protruded portion of the specimen was built, it accumulated more heat, which led to partial annealing in the process. This was reflected in lower hardness in these locations. By contrast, higher hardness and ultimate strength near the build platform may be due to incipient precipitation promoted by higher temperature due to slower cooling of a larger volume of material. This occurrence was reported in [16], where hardening temperatures as low as $350^{\circ} \mathrm{C}$ and longer holding times led to increasing mechanical properties. Mechanical testing confirmed that heat treatment with short holding times eliminates the effects of the build height and equalizes mechanical properties within the single part.

\section{Conclusion}

Effects of various height of builds on microstructural evolution after building and heat treatment were studied experimentally. For this purpose, a bushing specimen was built from MS1 maraging steel together on the build platform with a notably lower build. It was found that building parts of different height leads to a macroscopic visible change in the transition region between the uniform-height builds across the platform and a projecting part, which is reflected in a substantial decrease in hardness. In this location, hardness dropped from 360 to 320 HV10. Ultimate strength decreased with increasing build height from $1048 \mathrm{MPa}$ to $927 \mathrm{MPa}$. In the transition region, there was no local drop in ultimate strength, which would make it a critical location of the build.

Solution annealing $820^{\circ} \mathrm{C}$ as short as 1 hour removed the step change in hardness and equalized mechanical properties across the specimen. The highest ultimate strength was obtained with 3 hour solution annealing at $820^{\circ} \mathrm{C}$. After this treatment, the ultimate strength was close to $1000 \mathrm{MPa}$.

\section{Acknowledgement}

The present contribution has been prepared under project ITI CZ.02.1.01/0.0/0.0/18_069/0010040, “Research of additive technologies for future application in mechanical engineering practice - RTI plus" under the auspices of the National Sustainability Programme I of the Ministry of Education of the Czech Republic aimed to support research, experimental development and innovation.

\section{References}

[1] ZHIYUAN L., DANDAN Z., PEI W., MING Y., CAN Y., ZHANGWEI CH., JIAN L., ZHAOPING L. (2021). Additive manufacturing of metals: Microstructure evolution and multistage control. In: Journal of Materials Science and Technology, in press. Elsevier. USA. ISSN 1005-0302

[2] KUČEROVÁ, L., ZETKOVÁ, I., JANDOVÁ, A., BYSTRIANSKÝ, M. (2019). Microstructural characterisation and in-situ straining of additive-manufactured X3NiCoMoTi 18-9-5 maraging steel. In: Materials Science and Engineering A, Vol. 750, pp. 70-80. Elsevier. USA. ISSN 0921-5093

[3] TAN, CH. et al. (2018) Microstructural evolution, nanoprecipitation behavior and mechanical properties of selective laser melted high-performance grade 300 maraging steel. In. Materials and Design, Vol. 134, pp. 23-34. Elsevier. ISSN 0264-1275

[4] HANZL, P., ZETKOVÁ, I. \& KUČEROVÁ, L. (2019) Structural changes and microstructure of maraging steel lattice structures using additive manufacturing. In: Manufacturing Technology, Vol. 19, No. 1, pp. 37-41. J. E. Purkyne Univeristy in Ústí nad Labem. Czech Republic. ISSN 1213-2489 
[5] MONKOVA, K. et al. (2019) Study of 3D printing direction and effects of heat treatment on mechanical properties of MS1 maraging steel. In: Archive of Applied Mechanics, Vol. 89, No. 5, pp. 791-804. Springer-Verlag GmbH. Germany. Switzerland. ISSN 1432-0681

[6] HANZL, P., ZETKOVÁ, I., DAŇA, M., NOZAR, M. (2020). Advanced Simulation of Metal Additive Manufacturing Using Maraging Steel and Nickel Alloy. In.: Manufacturing Technology, Vol. 20, No. 3, pp. 313-317. J. E. Purkyne University in Ústí nad Labem. Czech Republic. ISSN 1213-2489

[7] MUTUA, J., NAKATA, S., ONDA T., CHEN, Z.-CH. (2018). Optimization of selective laser melting parameters and influence of post heat treatment on microstructure and mechanical properties of maraging steel. In: Materials and Design, Vol. 139, pp. 486-497, Elsevier. USA. ISSN 0264-1275

[8] MENEGHETTI, G., RIGON, D., COZZI, D., WALDHAUSER, W. \& DABALÀ, M. (2017) Influence of build orientation on static and axial fatigue properties of maraging steel specimens produced by additive manufacturing. In: Procedia Structure Integrity, Vol. 7, 149157. Elsevier. USA. ISSN 2452-3216

[9] BAI, Y., YANG, Y., WANG, D. \& ZHANG, M. (2017) Influence mechanism of parameters process and mechanical properties evolution mechanism of maraging steel 300 by selective laser melting. In: Materials Science and Engineering A, Vol. 703, pp. 116-123. ISSN 0921-5093

[10] KEMKEN, K., YASAA, E., THIJSB, L., KRUTHA, J.-P., VAN HUMBEECK, J. (2011) Microstructure and mechanical properties of Selective Laser Melted 18Ni-300 steel. In: Physics Procedia, Vol. 12, pp. 255-263. ISSN 18753892
[11] EOS MaragingSteel MS1, EOS, online [201908-28], https://cdn.eos.info/1deee2b550955632/b36 15b8 0c80a/MS-MS1M290_Material_data_sheet_10-17_en.pdf

[12] Data sheet MS1, online [2021-08-24], http://www.matweb.com/search/DataSheet.aspx?MatGUID=39e11302430d4e18bb59280448a1c972 $\& \mathrm{ckck}=1$

[13] SHUO YIN, et al. (2018) The influence of aging temperature and aging time on the mechanical and tribological properties of selective laser melted maraging $18 \mathrm{Ni}-300$ steel. In: Additive Manufacturing, Vol. 22, pp. 592-600, Elsevier. USA. ISSN 2214-8604.

[14] SURYAWANSHI, J., PRASHANTH, K.G., RAMAMURTY, U. (2017) Tensile, fracture, and fatigue crack growth properties of a $3 \mathrm{D}$ printed maraging steel through selective laser melting. In: Journal of Alloys Comounds, Vol. 725, pp. 355-364, Elsevier. USA. ISSN 0925-8388

[15] CASATI, R., LEMKE, J., VEDANI, M. (2017) Microstructural and Mechanical Properties of As Built, Solution Treated and Aged $18 \mathrm{Ni}$ (300 grade) Maraging Steel Produced by Selective Laser Melting. In: La Metallurgia Italiana. Vol. 109, No. 1, pp. 11-20. AIM. Italy. ISSN 00260843

[16] KUČEROVÁ, L., BURDOVÁ, K., JENÍČEK, Š., CHENA, I. (2021) Effect of solution annealing and precipitation hardening at $250^{\circ} \mathrm{C}-$ $550^{\circ} \mathrm{C}$ on microstructure and mechanical properties of additively manufactured 1.2709 maraging steel, In: Materials Science and Engineering: $A$, Vol. 814, pp. 141195, Elsevier. ISSN 0921 5093 